\title{
Editorial: Aggregate - a question of responsible use
}

\section{Ravindra K Dhir OBE}

Professor, University of Birmingham, UK; Trinity College Dublin, Ireland; and University of Dundee, UK

As creatures of habit, rational thinking can often become ignored over a long time period. Indeed, the status of recycled and secondary aggregates (RSAs) in the concrete construction industry is one such classic example. In this respect, this special themed issue of Magazine of Concrete Research on the subject of the use of RSAs in concrete construction is timely and to be welcomed.

In addressing this, it would help to start with the basics by defining the function of aggregate in concrete. In the simplest terms, aggregates in concrete provide relatively low-cost filler and as a mass of particles they resist the action of applied loads and volume changes resulting from setting/hardening of and moisture changes in the cement paste, and thereby contribute to the strength and durability of concrete. This performance-based role of aggregate in concrete leaves open the choice of source material. In a rational approach, the source of aggregate should be based on matching its quality with the required concrete performance, thus leading to the appropriate use of all sources of aggregates - such as virgin aggregates derived from rock quarries or sand and gravel deposits, recycled aggregates arising from construction demolition and excavation waste and secondary aggregates arising from industrial by-products and industrial/ domestic wastes.

Clearly, the rationale of suitable materials for suitable applications is progressing very slowly. A literature search confined to recycled aggregates and few specific secondary aggregates, namely glass cullet, copper slag and incinerated bottom ash, has produced a list of 6000 papers published during the last 40 years. The governments world-over individually and collectively through international cooperation are forging ahead with the sustainability agenda, which is encouraging the concrete industry to adopt sustainable construction by maximising the use of RSA. However, only a tiny proportion of the 30 billions of tonnes of virgin aggregates used worldwide are being replaced by RSA. Why? Does the construction industry still lack confidence in making responsible use of aggregate in concrete? Or do the standards and codes of practice need to shift further to allow engineers to specify these materials. Perhaps further efforts are required on the part of aggregate and concrete producers, researchers and engineers in order to remove the stigma that is attached to the use of RSAs.

This themed issue contains 13 papers originating from Australia,
Belgium, China, Croatia, Japan, Singapore, South Korea, Spain and the UK. Although these papers do not cover the full spectrum of RSA currently available to the concrete construction industry, they do make a considerable contribution towards developing responsible use of RSA in concrete production. This makes this issue a valuable reference source.

The most important aspects of producing RSA, as with natural aggregates, are the quality and consistency of the material produced and together these can make a considerable impact on the specifier and development of a responsible use of recycled concrete aggregates (RCAs) in construction. In the first paper of the issue, Akbarnezhad and Moussavi Nadoushani (2015) describe the state-of-the-art concrete recycling technology that allows the quality of the coarse RCAs to be regulated, as well as determine the optimal recycling method by applying trade-offs between cost, energy use and $\mathrm{CO}_{2}$ emissions associated with producing of RCA. An illustrated example is provided. The next paper, by Collery et al. (2015), draws together several studies undertaken by the authors themselves over a period of 18 years, and they have been innovative in bringing together all the natural, recycled and manufactured aggregates under the umbrella of normal weight aggregates as per BS EN 12620. This should remove the stigma attached to recycled and manufactured materials. The paper also paves the way for applying a performance-based approach in developing a responsible use of aggregates in practice.

The next four papers bring out some pertinent and much needed information. Banjad Pečur et al. (2015) describe their innovative and challenging research and development work with the fabrication of precast concrete panels using mixtures of concrete and brick aggregates, with the aim of reducing embodied energy use and $\mathrm{CO}_{2}$ emissions. The paper by Park et al. (2015) brings together vast amounts of data (1300) from the studies undertaken over a 30-year period (1980-2012), using recycled aggregate concrete in Japan and Korea to statistically analyse and develop relationships between compressive strength and modulus of elasticity. Joseph et al. (2015) present pertinent information from their study on the water absorption properties of coarse RCA on the resulting concrete performance in both the fresh and hardened states. Based on the extensive studies undertaken over the years using both the ASTM C1260 and BS 812-123 test methods, McCarthy et al. (2015) have provided in detail much needed information on the alkali-aggregate reaction, with the testing of 
concrete made with recycled aggregates arising from a wide range of masonry units, concrete, demolition waste, road planings, slate and plasterboard.

Yang and Hou (2015) examine the performance of recycled aggregate concrete for structural applications in the form of concrete-filled steel tubes, subjected to short-term static loading, long-term sustained loading and cyclic flexural loading. Their study shows, in general, that steel-concrete composite members behave normally when recycled aggregates are used. Jang and Yun (2015) report on the use of fine recycled aggregates at up to $100 \%$ replacement level in a ready-mixed concrete environment. Some very useful data have been provided on the performance of concrete in the fresh state (slump and air content) and hardened state (strength, drying shrinkage, creep, flexural, shear and bond performance). Ho et al. (2015) describe the results of an extensive study undertaken, which is essentially a case study, covering a very wide range of tests for engineering and durability properties of concrete containing up to $100 \%$ coarse recycled concrete as aggregate. This study led to the successful completion of the fully functional Samwoh Eco-Green Building. The work of Etxeberria and Vegas (2015) is a departure from the norm and is very interesting as it explores the use of fine aggregates arising from rejected ceramic waste crushing on their own and mixed with those arising from the construction demolition waste crushing process. Useful data is provided that shows the potential use of the ceramic fines in concrete.

The closing studies presented in this themed issue address the use in concrete of secondary aggregates. Jones et al. (2015) describe a feasibility study of their innovative technology of converting into lightweight manufactured sand, by using foamed concrete, the silt size fractions arising from quarry fines, a construction demolition crushing process and various industrial wastes. Lye et al. (2015) provide the outcome of their state-of-the-art review of the use of copper slag (CS) and washed copper slag (WCS) with systematic analysis and evaluation of the massive data assembled, showing how CS/WCS as a component of sand can be used and, in so doing, make other recycled and secondary materials more acceptable for their use in concrete. The study by Su et al. (2015) describes their development work undertaken to improve, through surface treatment, the bond between the used tyre rubber crumb fine aggregates and the cement matrix, which resulted in minimising strength losses of concrete. Such a concrete has been shown to develop improved engineering and permeation properties of concrete.

Together, the papers published in the issue provide an international flavour and they contain a wealth of new knowledge, both innovative and pragmatic, and in a form that will help to bring about changes in the approach to using RSAs in concrete construction. In this respect, this themed issue has been a success and suggests that it would be worthwhile for the Magazine of Concrete Research to consider bringing out a second issue on this theme soon.

\section{REFERENCES}

Akbarnezhad A and Moussavi Nadoushani ZS (2015) A computational method for selection of optimal concrete recycling strategy. Magazine of Concrete Research 67(11): 543-558, http://dx.doi.org/10.1680/macr.14.00211.

Banjad Pečur I, Štirmer N and Milovanović B (2015) Recycled aggregate concrete for nearly zero-energy buildings. Magazine of Concrete Research 67(11): 575-584, http:// dx.doi.org/10.1680/macr.14.00220.

Collery DJ, Paine KA and Dhir RK (2015) Establishing rational use of recycled aggregates in concrete: a performance-related approach. Magazine of Concrete Research 67(11): 559-574, http://dx.doi.org/10.1680/macr.14.00206.

Etxeberria M and Vegas I (2015) Effect of fine ceramic recycled aggregate (RA) and mixed fine RA on hardened properties of concrete. Magazine of Concrete Research 67(12): 645-655, http://dx.doi.org/10.1680/macr.14.00208.

Ho NY, Lee YPK, Lim WF et al. (2015) Evaluation of RCA concrete for the construction of Samwoh Eco-Green Building. Magazine of Concrete Research 67(12): 633-644, http:// dx.doi.org/10.1680/macr.14.00212.

Jang SJ and Yun HD (2015) Mechanical properties of readymixed concrete incorporating fine recycled aggregate. Magazine of Concrete Research 67(12): 621-632, http:// dx.doi.org/10.1680/macr.14.00258.

Jones MR, Halliday JE, Csetenyi LJ, Zheng L and Strompinis N (2015) Feasibility of utilising quarry fine and waste silts to manufacture synthetic lightweight sand. Magazine of Concrete Research 67(12): 656-664, http://dx.doi.org/ 10.1680/macr.15.00201.

Joseph M, Boehme L, Sierens Z and Vandewalle L (2015) Water absorption variability of recycled concrete aggregates. Magazine of Concrete Research 67(11): 592-597, http:// dx.doi.org/10.1680/macr.14.00210.

Lye CQ, Koh SK, Mangabhai R and Dhir RK (2015) Use of copper slag and washed copper slag as sand in concrete: a state-ofthe-art review. Magazine of Concrete Research 67(12): 665679, http://dx.doi.org/10.1680/macr.14.00214.

McCarthy MJ, Csetenyi LJ, Halliday JE and Dhir RK (2015) Evaluating the effect of recycled aggregate on damaging AAR in concrete. Magazine of Concrete Research 67(11): 598-610, http://dx.doi.org/10.1680/macr.14.00260.

Park WJ, Noguchi T, Shin SH and Oh DY (2015) Modulus of elasticity of recycled aggregate concrete. Magazine of Concrete Research 67(11): 585-591, http://dx.doi.org/ 10.1680/macr.14.00213.

Su H, Yang J, Ghataora GS and Dhirar S (2015) Surface modified used rubber tyre aggregates: effect on recycled concrete performance. Magazine of Concrete Research 67(12): 680691, http://dx.doi.org/10.1680/macr.14.00255.

Yang YF and Hou C (2015) Behaviour and design calculations of recycled aggregate concrete-filled steel tube (RACFST) members. Magazine of Concrete Research 67(11): 611-620, http://dx.doi.org/10.1680/macr.14.00204. 